\title{
Features of Soil Tillage during the Cultivation of Spring Barley
}

\author{
Yulia Semenikhina ${ }^{1}$, Sergey Kambulov ${ }^{1}$, Dmitriy Podlesniy ${ }^{2,}$, and Andrey Boyko ${ }^{2}$ \\ ${ }^{1}$ State Scientific Establishment "Agricultural Research Center "Donskoy", Russian Federation, \\ Zernograd, Lenin st., 14 \\ ${ }^{2}$ Don State Technical University, Russian Federation, Rostov-on-Don, Gagarin Square, 1
}

\begin{abstract}
Spring barley is a multipurpose crop. High-quality and valuable grain is grain with a high protein content, which is formed at high temperatures in the phase of grain filling. But droughty conditions are unfavorable for the entire growing season of plants. Therefore, the cultivation of spring barley in an arid climate requires a competent approach and is based on a rational combination of agrotechnical methods, among which a special place is given to the main tillage. The purpose of the research is to establish the effect of various methods of soil cultivation on soil moisture and density, as well as on the yield of barley. We studied 4 options for soil cultivation: deep flat-cut, deep layer-by-layer non-moldboard, deep moldboard plowing and direct sowing without tillage. According to the results of the research, the highest soil moisture was established with direct sowing. A decrease in soil moisture was revealed for layer-by-layer tillage by $12.46 \%$, for flat-cut tillage by $13.83 \%$, for moldboard tillage by $15.84 \%$. Studies of soil density by the phases of development of spring barley for each of the methods of soil cultivation have established an increase in density with depth. The highest yield of spring barley was obtained with direct sowing. At the same time, it exceeded the yield with the dump method of tillage by $4.37 \%$, with the layerby-layer method by $14.48 \%$ and with the flat-cut method of tillage by $17.26 \%$. Thus, in arid conditions, direct sowing provided the best results in soil moisture and yield in the cultivation of spring barley
\end{abstract}

\section{Introduction}

Spring barley is a multipurpose crop. In the food sector, it is used as cereal products; feed grain and straw are used in the stern direction; in the technical direction they are used for the brewing industry [1]. At the same time, high-quality and valuable for food purposes is grain with a high protein content, which is formed exclusively in arid conditions [2]. And if in the phase of grain filling with its subsequent harvesting dry conditions and high air temperature are the most favorable, for the rest of the growing season, such conditions can adversely affect the development of plants as a whole [3].

Therefore, the cultivation of spring barley in an arid climate with insufficient moisture [4] requires a competent approach and is based on a rational combination of agricultural

\footnotetext{
* Corresponding author podlesniy.dmitri@yandex.ru
} 
techniques, among which a special place is given to the main tillage [5]. The task of tillage is to form a loose soil structure. Space-time changes take place in the treated volume of soil. Soil aggregates interconnected layer by layer acquire a soil skeleton with a chaotic distribution in the inter-aggregate space with macro- and micropores [6]. Under such conditions, the process of thermal diffusion contributes to the long-term preservation of soil moisture. Moreover, the process itself is interrelated with atmospheric phenomena. In arid conditions, fluctuations in seasonal, day and night temperatures of air and soil determine the magnitude and direction of movement of soil moisture inside the soil layer in the form of soil vapor [7]. In this connection, tillage must ensure the movement of moisture within the soil layer and at the same time prevent evapotranspiration. For the formation of a favorable soil structure $[8,9]$, various methods of its cultivation are used: dump, dump-free, layer-by-layer, surface or cultivation of agricultural crops without soil cultivation [10].

The choice depends on climatic and soil conditions, on the crop rotation of agricultural crops, on the granulometric composition of the soil, on erosion and other factors. Therefore, it is advisable to use adaptive agrotechnical methods aimed at moisture-saving soil cultivation.

The purpose of our research was to study various methods of soil cultivation that promote optimal soil moisture and density, as well as a stable yield of spring barley.

\section{Materials and methods}

When cultivating spring barley, the influence of various methods of basic tillage on soil moisture and density, and on yield was studied. For the research, many years of stationary experience were laid. The cultivated crop is spring barley. The predecessor is soy.

We studied 4 options for soil cultivation: deep flat-cut, deep layered non-moldboard, deep moldboard plowing and direct sowing without tillage. Repetition - threefold. Figure 1 shows the tillage implements for different methods of soil cultivation.

In the first variant, the main deep flat-cut tillage was carried out with a combined unit UNS-3 to a depth of 20-25 cm. In one pass of the unit across the field, its working bodies carried out deep moldboard-free flat-cutting processing with subsoil furrowing and the formation of a water-retaining layer by a roller. The principle of operation of the unit was as follows. The main loosening work was performed by a flat-cutting narrow-grip share (Fig. 1a). Due to the fact that the wings and the center of the paw are equipped with three-row wedges tops forward in the direction of movement of the organ, the undercut soil layer was lifted along the edges and edges of the wedges. In the course of movement, the layer was stretched and fractured. At the same time, the wedges of the paws formed subsoil furrows molehills capable of accumulating moisture. At the same time, weeds were cut. The process of deep loosening was completed by the action of a cutting-mulching roller, which crushed lumps, broke clods, compacted and mulched the surface layer. Thus, the flat-cut method of deep tillage loosened the soil with partial preservation of crop residues, which additionally contributed to moisture conservation and prevention of soil erosion processes.

In the second variant, the main deep moldboard-free layered tillage was carried out with the KAO-2 unit. The soil was loosened by a combined working body (Fig. 1b). On the counter of the working body, an asymmetric share is used to cultivate the soil at a depth of $8-10 \mathrm{~cm}$. The operation of loosening is as follows: the first tier in the form of a flat-cutting share cut the top layer of the soil and leaves it loosened without turning the layer. The main cultivator, at a depth of $25 \mathrm{~cm}$, trimmed the main soil monolith, which moved along the surface of the bit. As a result of this process, stress is distinguished in the volume of the entire cut monolith, leading to spatial crevice formation. The mutual intersection of inclined, horizontal and vertical slits formed voids, macro- and micropores, capable of accumulating soil moisture. The deep loosening process is completed by the rolling operation with a mulching roller, 
which loosened and mixed the soil along with the crop residues, leveled and simultaneously compacted the surface layer. During layer-by-layer cultivation, the soil layers were not mixed, and the stubble was also partially preserved.

a)

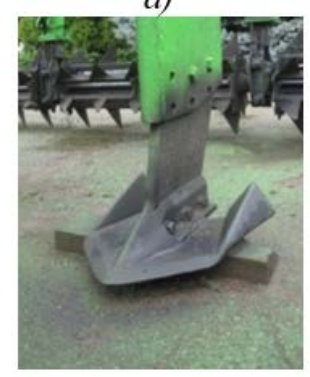

c)

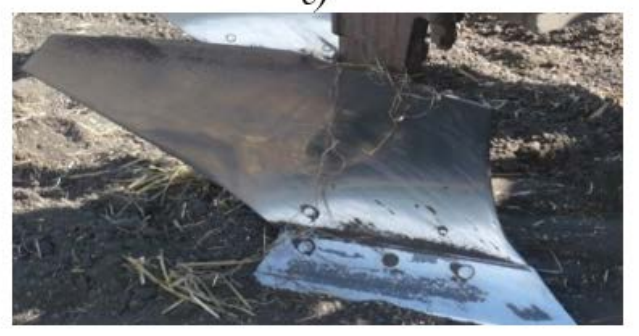

b)

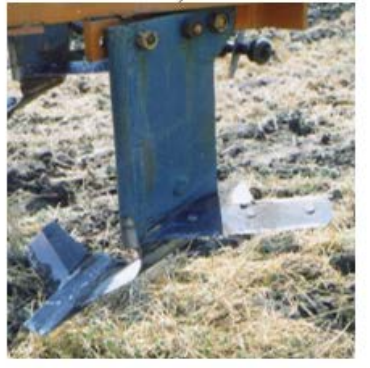

d)

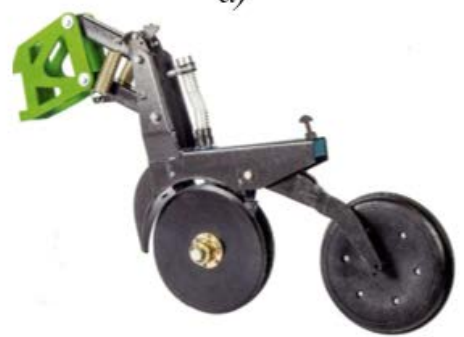

Fig. 1. Tillage working bodies: a) flat ripper with wedges; b) combined working body; c) dump body; d) double disc coulter

The third option for basic tillage was classical plowing. It was carried out by the moldboard method with a single-operation plow PN5-35 to a depth of 22-25 cm. The soil was loosened by the dump body (Fig. 1c). The process of its work consists in cutting the soil layer from below, raising it and directing it to the dump, from which the soil layer shifted, partially crumbled and turned around. As a result, stubble and plant residues turned out to be embedded, and moist soil layers were brought to the surface and immediately dried up due to the absence of a mulching layer. From the point of view of moisture saving, this method is the least preferable. In addition, after the dry summer period, the field was lumpy.

The fourth option excluded any tillage. The seeds were embedded in the soil with doubledisc openers (Fig. 1d). The mulch and soil layer was cut by coulters installed in front of the openers. This impact on the soil was single and minimal. The remaining plant residues from the previous crops accumulated and formed a mulch covering, which served as a preserving function for soil moisture and a protective function against soil erosion.

Soil and climatic conditions were taken into account. The soil of the experimental site is represented by ordinary calcareous heavy loamy chernozem. Content of humus in the arable layer of soil: - 3.4\%; pH - 6.9-7.5; P2O5 - 21.2-24.71 mg / kg; K2O - 341-372 mg / kg of soil. During the growing season of spring barley, weather conditions differed in the amount of precipitation and air temperature. In the 2018 agricultural year, precipitation fell unevenly over the seasons, their sum was $103 \%$ of the norm, and the average monthly air temperature was higher than the average annual (by 114\%). In 2019, a slight excess of precipitation was recorded (108\% of the multi-year norm) and an increased temperature regime of the air (126\% of the norm). In the 2020 agricultural year, the amount of precipitation and the average daily temperature exceeded the climatic norm by 106 and $112 \% \%$ of the multiyear norm.

The study of the dynamics of soil moisture was carried out using field weather stations 
Watch Dog 1400 in an autonomous mode. The recorder, placed in a moisture-proof housing, and a humidity sensor were sealed at a depth of $30 \mathrm{~cm}$ at a distance of meters from each other. The recorder was configured to record indicators with an interval of 1 hour (60 $\mathrm{min}$ ) and fix them on the internal memory. Once a month, the indicators were taken for further analysis in laboratory conditions. Figure 2 shows a logger with a sensor and the process of transferring (copying) soil moisture data. The work of the recorder and further work with it was provided by the SpecWare 9 Basic software.

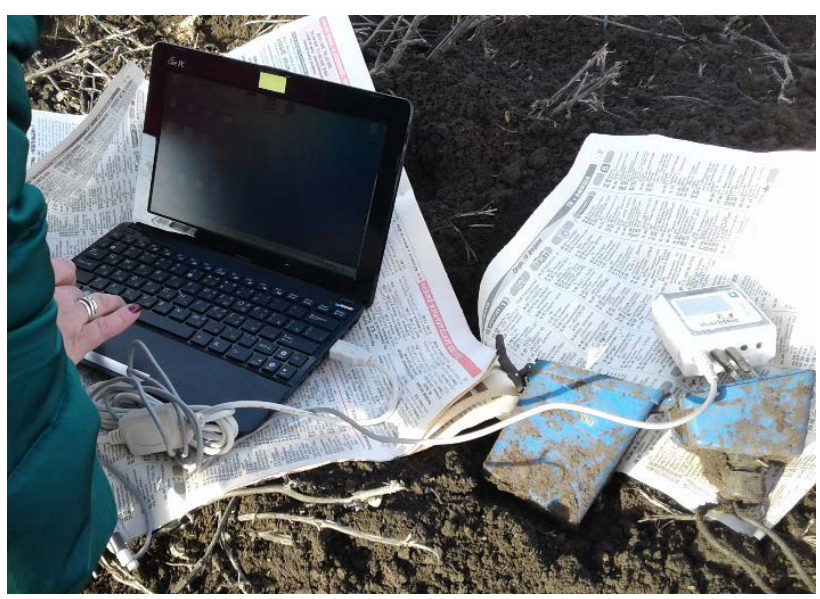

Recorder

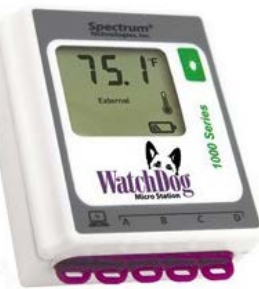

Soil moisture sensor

Fig. 2. Investigation of soil moisture in the field: the field weather station - Watch Dog 1400 Micro recorder and soil moisture sensor

The soil moisture and temperature sensors were placed in the soil horizon at a depth of $30 \mathrm{~cm}$. The results of the indicators were recorded in one hour increments and automatically recorded on the internal memory of the Watch Dog 1400 weather station recorder. Once a month, the data were retrieved and adjusted to daily average values.

The research of soil density under crops of spring barley was carried out by the volumeweight method layer by layer $(0-10 \mathrm{~cm}, 10-20 \mathrm{~cm}, 20-30 \mathrm{~cm})$, taking into account the phase of plant development.

The yield of spring barley was determined by a direct method. The obtained data were processed in Microsoft Excel. Data are presented as arithmetic means.

\section{Research results}

The averaged data on the influence of various methods of processing on its moisture content during three years of research are presented in Table 1. Their analysis shows the advantage of direct sowing in terms of soil moisture content over the entire observation period. Soil indicators for different tillage methods have a similar picture for 2018 and 2020. The most moistened soil on the experimental plots was noted with the use of direct sowing - 53.25 and $51.62 \% \%$, respectively. The soil cultivated by layer-by-layer method occupied the second position, respectively 47.28 and $44.50 \% \%$. In 2018 and 2020, flat-cut soil cultivation took the third position $-46.18 \%$ and $43.81 \%$. The lowest soil moisture was recorded under the dumping method of processing, respectively, $44.24 \%$ and $42.51 \%$. In 2019 , the redistribution of positions in the presence of soil moisture occurred only in deep loosening methods of tillage. 
Table 1. The results of the investigation of soil moisture by years depending on the methods of basic soil cultivation at a depth of $30 \mathrm{~cm}, \%$

\begin{tabular}{|l|c|c|c|c|c|}
\hline $\begin{array}{c}\text { Method of basic } \\
\text { tillage }\end{array}$ & $2018 \Gamma$. & $2019 \Gamma$. & $2020 г$. & $\begin{array}{c}\text { Average, } \\
\text { t } / \text { ha }\end{array}$ & $\begin{array}{c}\text { Change to } \\
\text { average, } \%\end{array}$ \\
\hline Flat-cut cultivation & 46,18 & 41,42 & 43,81 & 43,80 & $\mathbf{8 6 , 1 7}$ \\
\hline Layered cultivation & 47,28 & 39,94 & 46,27 & 44,50 & $\mathbf{8 7 , 5 4}$ \\
\hline $\begin{array}{l}\text { Moldboard } \\
\text { cultivation }\end{array}$ & 44,24 & 41,60 & 42,51 & 42,78 & $\mathbf{8 4 , 1 6}$ \\
\hline $\begin{array}{l}\text { No tillage - direct } \\
\text { sowing }\end{array}$ & 53,25 & 45,64 & 51,62 & 50,17 & $\mathbf{1 0 0}$ \\
\hline
\end{tabular}

For flat-cut and moldboard tillage, there are practically equivalent indicators of soil moisture $-41.42 \%$ and $41.60 \%$. Under layer-by-layer cultivation, the soil turned out to be the least wet - 39.94\%. This distribution of data in 2019 is explained by an extremely dry year, when an increased temperature regime of the air was recorded, as a result of which the evaporation processes were intense.

The average indicates that the moisture content of the untreated soil is always high. Relative to it, a decrease in soil moisture was first noted for layer-by-layer processing by $12.46 \%$, then for flat-cut processing by $13.83 \%$, and finally for moldboard processing by $15.84 \%$. From which it follows that among the deeply loosening methods of soil cultivation for the accumulation of soil moisture, the dump is the least preferred.

Data on soil density depending on the method of soil cultivation and on the phases of development of spring barley for a three-year period are presented in Table 2.

Table 2. Results of a layer-by-layer study of soil density in vases of spring barley development depending on the soil cultivation system, $\mathrm{g} / \mathrm{cm} 3$

\begin{tabular}{|l|c|c|c|c|c|}
\hline $\begin{array}{l}\text { Phase of } \\
\text { development }\end{array}$ & $\begin{array}{l}\text { Soil } \\
\text { layer, cm }\end{array}$ & $\begin{array}{l}\text { Moldboard } \\
\text { cultivation }\end{array}$ & $\begin{array}{l}\text { Layer } \\
\text { cultivation }\end{array}$ & $\begin{array}{l}\text { Flat-cut soil } \\
\text { cultivation }\end{array}$ & $\begin{array}{l}\text { No tillage - } \\
\text { direct sowing }\end{array}$ \\
\hline Seedlings & $0-10$ & 1,01 & 1,05 & 1,03 & 1,09 \\
& $10-20$ & 1,08 & 1,12 & 1,10 & 1,20 \\
& $20-30$ & 1,21 & 1,22 & 1,23 & 1,23 \\
\hline Bloom & $0-10$ & 1,16 & 1,14 & 1,13 & 1,11 \\
& $10-20$ & 1,21 & 1,19 & 1,22 & 1,22 \\
& $20-30$ & 1,28 & 1,26 & 1,31 & 1,26 \\
\hline Before & $0-10$ & 1,22 & 1,22 & 1,24 & 1,21 \\
cleaning & $10-20$ & 1,29 & 1,27 & 1,28 & 1,26 \\
& $20-30$ & 1,34 & 1,31 & 1,31 & 1,29 \\
\hline
\end{tabular}

From the analysis of the table, it follows that according to the shoots of spring barley, the most dense soil was recorded under direct sowing for each layer. In the 0-10 cm soil layer during the flowering phase and before harvesting, the uncultivated soil (direct sowing) was less dense than the soil that was subjected to various soil cultivation methods.

In general, in all the studied phases of the development of spring barley for each of the methods of tillage and direct sowing, an increase in soil density was observed with the depth of its cultivation. However, with a layer-by-layer comparison of soil horizons $(0-10 \mathrm{~cm}, 10$ $20 \mathrm{~cm} .20-30 \mathrm{~cm}$ ) between the cultivated methods, it follows that during the flowering phase and before harvesting, the soil density under direct sowing had equal or reduced values. This is because the available soil moisture prevents soil compaction.

The research on the yield of spring barley for three years are presented in Table 3. From its analysis it follows that in 2018 and 2019, a low yield was noted compared to 2020. On 
average, among the methods of tillage during three years of observation, the highest yield was recorded with direct sowing. However, there are differences for each year separately.

Table 3. Results of the study on the yield of spring barley depending on the method of tillage, $t /$ ha

\begin{tabular}{|l|c|c|c|c|c|}
\hline \multirow{2}{*}{ Tillage method } & \multicolumn{3}{|c|}{ The years of research } & \multirow{2}{*}{$\begin{array}{c}\text { Average, } \mathrm{t} \\
\text { / ha }\end{array}$} & $\begin{array}{c}\text { Change to } \\
\text { average, } \%\end{array}$ \\
\cline { 2 - 4 } & 2018 & 2019 & 2020 & 3,69 & $\mathbf{8 2 , 7 4}$ \\
\hline Flat-cut soil cultivation & 2,43 & 2,13 & 6,51 & 3,81 & $\mathbf{8 5 , 4 2}$ \\
\hline Layer tillage & 2,45 & 1,74 & 7,24 & 3,81 & $\mathbf{9 6 , 6 3}$ \\
\hline Moldboard cultivation & 3,05 & 2,34 & 7,53 & 4,31 & $\mathbf{1 0 0}$ \\
\hline $\begin{array}{l}\text { No tillage - direct } \\
\text { sowing }\end{array}$ & 3,85 & 3,43 & 6,09 & 4,46 & \\
\hline
\end{tabular}

In 2018, low yield was recorded under flat-cut and layer-by-layer tillage, 2.43 and $4.45 \mathrm{t}$ / ha, respectively. The average yield was $3.05 \mathrm{t} /$ ha under the moldboard tillage. High yield of barley was obtained with direct sowing $-3.85 \mathrm{t} /$ ha.

In 2019, the highest yield of spring barley was obtained with direct sowing $-3.43 \mathrm{t} /$ ha. The lowest yield of $1.74 \mathrm{t} /$ ha was obtained with the dump method of tillage. The yield under flat-cut and layer-by-layer tillage was slightly different, 2.13 and $2.34 \mathrm{t} / \mathrm{ha}$, respectively.

In 2020, yields have increased significantly for all tillage methods. However, with direct sowing, the yield of barley was the lowest, $6.09 \mathrm{t} / \mathrm{ha}$. With the flat-cut method of processing, the yield was $6.51 \mathrm{t} / \mathrm{ha}$. An even greater yield was obtained with layer-by-layer tillage of $7.24 \mathrm{t} / \mathrm{ha}$. And the highest yield of $7.53 \mathrm{t} /$ ha was obtained with moldboard soil cultivation.

The average yield indicators over three years of observations indicate that the yield obtained by direct sowing is the highest among other methods of soil cultivation. At the same time, it exceeds the yield with the dump method of tillage by $4.37 \%$, with the layer-by-layer method by $14.48 \%$ and with the flat-cut method of tillage by $17.26 \%$.

Statistical processing established an average direct correlation between the indicators of barley yield and soil moisture $r=+0.56$, which proves the significant effect of soil moisture on the formation of stable yields.

Thus, in conditions of insufficient moisture, direct sowing provides the best results in terms of yield, moisture and soil density when cultivating spring barley.

\section{Conclusion}

As a result of many years of research in the cultivation of spring barley in arid soil climatic conditions, the influence of various methods of soil cultivation on the indicators of soil moisture and density was revealed, and the yield of barley was determined.

The results of the study established the highest soil moisture with direct sowing. For deep loosening methods of soil cultivation, a decrease in soil moisture was established, first for layer-by-layer cultivation by $12.46 \%$, then for flat-cut cultivation by $13.83 \%$, and finally for moldboard cultivation by $15.84 \%$. Studies of soil density by the phases of development of spring barley for each of the methods of soil cultivation have established an increase in density with depth. When comparing the soil horizons between the cultivated methods, it was found that under direct sowing, the soil density had reduced values. The highest yield of spring barley was obtained with direct sowing. At the same time, it exceeded the yield with the dump method of tillage by $4.37 \%$, with the layer-by-layer method by $14.48 \%$ and with the flat-cut method of tillage by $17.26 \%$. 


\section{References}

1. L.J. Ludwig, V. Carpentieri-Pípolo, K.B.A. Lopes, E. Minella, A. Beleia, M.V.E. Grossmann, Rev. Bras. Cienc. Agrar., 14(4), 6942, (2019). https://doi.org/10.5039/agraria.v14i4a6942

2. M. Niero, C. Ingvordsen, P. Peltonen-Sainio, M. Jalli, M. F Lyngkjær, M. Z. Hauschild, R. B. Jørgensen, Agricultural Systems, 136, 46-60, (2015), doi:10.1016/j.agsy.2015.02.007

3. B. Ghimire, N. Maharjan, \& J. Dotel, Nep. J. Environ. Sci, 8, 53-67, (2020), https://doi.org/10.3126/njes.v8i1.35729

4. A. Shekhar, C.A. Shapiro, Soil and Tillage Research, 193, 161-170, (2019), https://doi.org/10.1016/j.still.2019.06.004

5. Yu.A. Semenikhina, S.I. Kambulov, G.G. Parkhomenko, A.A. Boyko, S.V. Ponomareva, S.V. Shvedova, A.F. Koltsov, E.O. Tsybenko, E3S Web of Conferences. XIII International Scientific and Practical Conference "State and Prospects for the Development of Agribusiness - INTERAGROMASH 2020” Rostov-on-Don, 09008, (2020), https://doi.org/10.1051/e3sconf/202017509008

6. X. Peng, R.Horn, and P. Hallett, Soil and Tillage Research, 146 (A), 1-3, (2015), doi.org/10.1016/j.still.2014.10.017

7. M. Kribaa, V.Hallaire, P. Curmi, R. Lahmar, Soil and Tillage Research, 60, 43-53, (2011), https://doi.org/10.1016/S0167-1987(01)00171-4

8. D.Kool, B. Tong, Z.Tian, J. L.Heitman, T. J.Sauer, R.Horton, Soil and Tillage Research, 193, 95-100, (2019), https://doi.org/10.1016/j.still.2019.05.020

9. V. Pandey, P. K. Pandey, Moisture International Journal of Geosciences, 1, 87-98, (2010), doi:10.4236/ijg.2010.12012

10. Y. Semenikhina, S. Kambulov, A. Boyko,Y. Nadolinsky and D. Podlesniy, IOP Conf. Ser.: Earth Environ. Sci., 723, 032048, (2021), doi:10.1088/1755-1315/723/3/032048 